
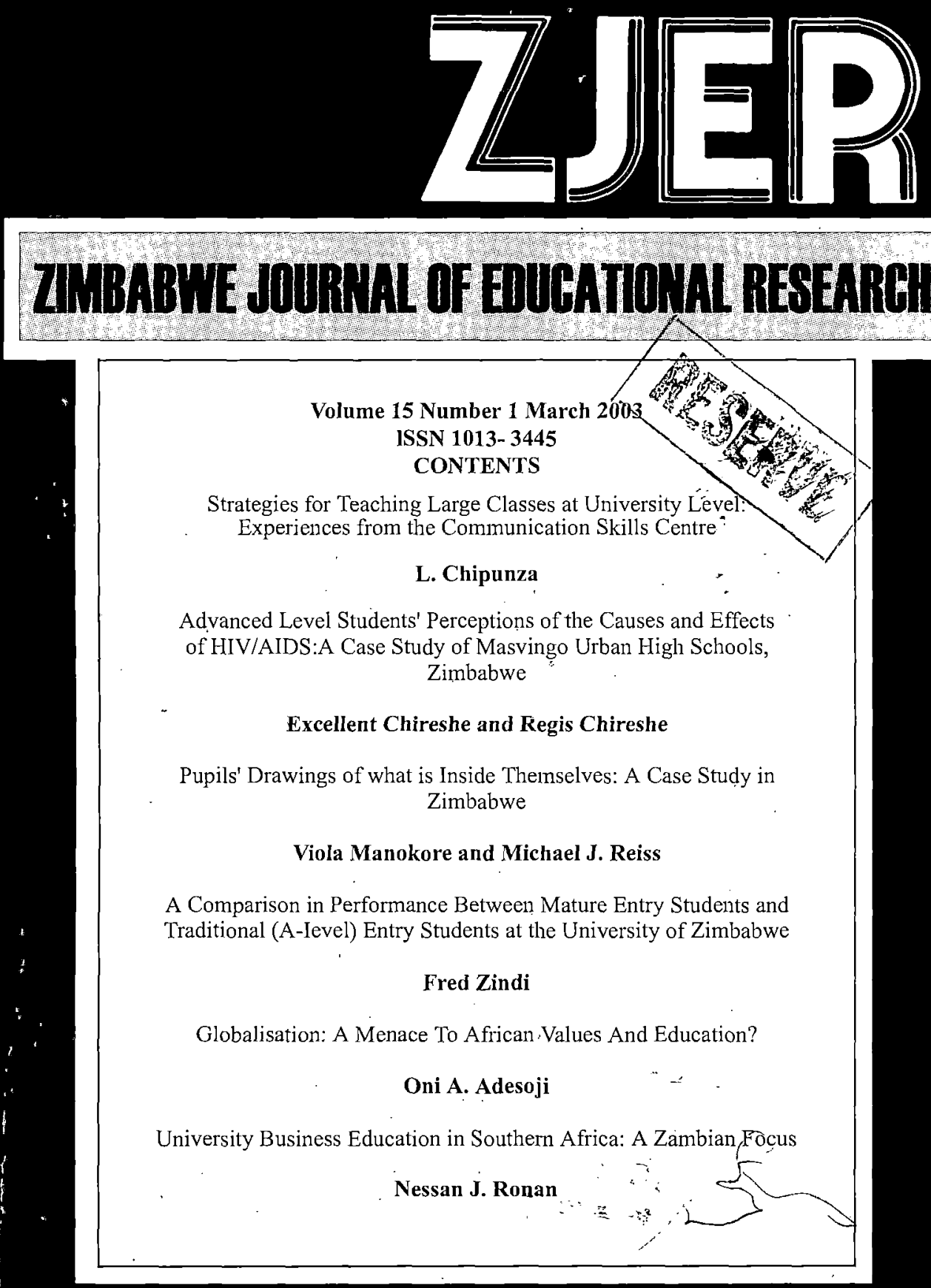


\title{
GLOBALISATION: A MENACE TO AFRICAN VALUES AND EDUCATION?
}

\author{
Oni A. Adesoji
}

\section{Abstract}

Globalisation has become a conspicuous phenomenon of our time and has attracted the attention of many. This paper examines the place of Africa in the global village by showing what the African continent stands to gain in the global community, whether globalisation portends any threat to African education and values and how best to make African education, cultures, and values functional and relevant in the new modernity.

\section{Introduction}

Today, we all talk about the world as a 'global village', a term first popularised by Mc Luhan in 1960 meaning "the world considered as a single community linked by satellites and telecommunications". From this, globalisation developed and was first used by The Spectator of October 5, 1962 in an article entitled "Globalization is, indeed a staggering concept".

Today, what is referred to as globalisation is complex: it may mean the transformation of the relationship among states and institutions; the universalisation of certain practices, the global restructuring of the recent decade since the dissolution of the Soviet Union and the hold of the defunct USSR on Eastern Europe or indeed the propagation of the structures of the. West's liberal capitalism to the rest of humanity. We discern a few facets to it: a sense of making universal certain issues such as sustainable development, human rights, environmental protection, and the universal fight against HIV/AIDS and a sense of remaking the world in terms of abolition of child labour, deregulation, privatisation, a world information and communication order or world democratisation, and the creation or dissolution of concepts like; self-determination, resource control or inequality.

The major concerns are many: will globalisation eclipse Africa and her people and obliterate her modest socio-cultural and economic achievements? Will globalisation usher Africa into a new phase of development, peace and progress that will enable her to take her rightful place in the community of nations? 
Does globalisation portend the further marginalisation of Africa and her people making them unequal partners in the global village? What does the African continent stand to gain in the global community? To what extent is it totality integrated? What are the global opportunities that have been or can be seized? And what are the threats of globalisation that are particularly challenging to Africa? How have the new characteristics of globalisation been reflected in Africa? Does globalisation portend any threat to African education and values? These questions guide the discussion in this paper.

\section{What is Globalisation?}

Globalisation has become a conspicuous phenomenon of our time and has captured the imagination of many. Some see it as the beginning of a new era, which promises integration and development for all, with technology, investment and trade overcoming geographical and economic isolation. Others understand globalisation as the acceleration of an on-going process of economic polarisation, in which more developed regions get richer, while countries in the periphery become further impoverished and politically unstable. However, despite this, there has been opposition against globalisation in recent times where people took to the streets to express their views.

Globalisation in practical terms could also be defined as the process by which enterprises related or unrelated become interdependent and inter-linked globally through strategic alliances and international networks. Adesanya (2000).

Kwanashie (1998) also defines globalisation as the process of integrating economic decision making such as the world, it is a process of creating a global market place in which, increasingly, all nations are forced to participate. It can also be described as the process of shifting autonomous economies into a global system of production and distribution. This emphasises an international cooperation that calls for adjustments by all participating countries.

Similarly Amin (in Kwanashie [1998]) sees globalisation as the establishment of a global market of goods and capital. It could also mean the universal character of competing technologies and the progression towards a global system of production. Hence, McGrew (1992, [in Kwanashie, 1998]) describes globalisation as the "forging of a multiplicity of linkages and interconnections between the states and societies which make up the modern world system. The processes by which events, decisions and activities in one part of the world can come to have significant consequences for individuals and communities in quite distant parts of the globe". Some, according to Adesanya 


\section{Ori A. Adesoji}

(2000) see it as the beginning of a new era, which promises integration, and development for all.

With the foregoing, globalisation can be understood as the acceleration of an ongoing process of economic polarisation. Thus, what is referred to as globalisation is complex, unwieldy, and currently considered all pervasive. It entails among others, the transformation of the relations between states, institutions, groups, and individuals.

In the same vein, Dembele in Adesanya (2000) posits that "globalization refers to the increased interdependence of the world economies, investment liberalization and deregulation policies". All these definitions suggest that globalisation implies the concrete structuration of the world as a whole; that is, a growing awareness at a global level that the world is a continuously constructed environment.

\section{Globalisation Theory}

Globalisation theory, according to Marshal (1994) examines the emergence of a global cultural system. It suggests that global culture is brought about by a variety of social and cultural developments: the existence of a world-satellite information system; the emergence of global patterns of consumption and consumerism, the cultivation of cosmopolitan life-styles; the emergence of global sport such as Olympic Games, World Football competitions, and international tennis matches, the spread of world tourism; the decline of sovereignty of the nation-state; the growth of a global military system; recognition of a world-wide ecological crisis; the development of world-wide health problems such as AIDS; the emergence of world political systems; such as the League of Nations and United Nations; the creation of global political movements such as Marxism; extension of the concept of human rights; and importantly, globalism involves a new consciousness of the world as a single place.

Globalisation is thus more than merely the sociology of international relations. It is also distinct from the world-system theory that has analysed the growth of a global economic interdependence, which claims that cultural globalism is simply the consequence of economic globalism. It is also important to avoid confusing the globalisation thesis with an earlier argument about the convergence of nation-states towards a unified and coherent form of industrial society. Contemporary globalisation theory argues that globalisation comprises two entirely contradictory processes of homogenisation and differentiation, which explain a complex interaction between localism and globalism. No won- 
der why there are powerful movements of resistance against globalisation processes.

The proponents of the theory are critical of traditional sociology, which continues to focus on the nation-state rather than the world as a system of societies. This explains that there are problems with globalisation theory. What, for example, is the distinction between globalisation and modern patterns of imperialism? There are also difficulties in specifying the relationships between economic and cultural globalisation, and between globalisation and modernization. Both theories and their problems are well illustrated in the essays collected in Albrow and King, Globalization, knowledge and society (1990).

\section{Challenges of Globalisation}

Globalisation has three main thrusts:

(a) Culture and civilisation: the propagation of mores, culture, and beliefs through global television stations and the internet/human rights, and abolition of capital punishment.

(b) Global economy through the World Trade Organization, open market, World Bank, the International Monetary Fund, etc.

(c) The expression of what is regarded as global political and military order, the Security Council of the UNO, UN's establishment of interventionist forces as peace monitors around the world and the International Court of Justice.

In all these, where do we see any input from African countries? Look at the whole spectrum: 54 years after, the founding of the United Nations, for example, its five-memiber veto-carrying countries of the Security Council have neither been enlarged nor has it any member from Africa, Latin America or any Third World country. True, the UN Secretary General comes from an African country, the second in the UN's 54 year history. Any of the five permanent members of the Security Council veto his reappointment and he knows it.

Of the 12 world languages spoken by over 50 million people, there was not a single African language listed except perhaps Arabic, which though adopted by North Africa is not, strictly speaking, an African language. Among these languages are Chinese, Hindi, Bengali, Japanese and Malay, speakers of which have adopted English as their second language. 


\section{Oni A. Adesoji}

Suppose Nigerians want to privatise their National Theatre for example, in the name of globalisation. Do we not realise how the English Language has gained her suzerainty as the undisputed global language through the efforts of the British Council, a U.K. state agency, and the United States Information Agency, all funded by their respective governments? Nigerian youths have caught on to American slang courtesy of American videotapes and diskettes. America sends jazz groups, drama groups, folklore and folk music groups all over the world to propagate her culture. So do the British. Each has established libraries everywhere in a bid not only to promote their language but also their culture. With regard to Africans, only a handful of political leaders plan to sustain theirs, not promote it, by selling their national theatre and other cultural heritage.

The West, and especially Britain and America stridently stress privatisation in the name of globalisation, removal of (oil) subsidies, etc. In the name of globalisation, Americans successfully lobbied some members of the Organization of Petroleum Exporting Countries (OPEC) for price reduction. For more than two years now, Nigeria has been lobbying America and Europe for debt cancellation without success: Global demography is indicating also that the West is becoming staid. Her population is ageing without replenishment, that Asia's and African economic boom in the next 100 years will far outstrip the West's. Apart from this hope, Africa ought to contribute to globalisation, her humanity, her cultural heritage and some values that colonisation has bastardised.

As a matter of principle, Africa supports free enterprise and by implication free trade. But in the interest of African countries' national interests, there is need to debate the impact of globalisation on the economy and how it should shape policies, after all. It should be remembered that just about a decade ago, there was hardly much talk about globalisation, although the move towards empire building, widening of frontiers and the search for new markets was evident. Today, the larger world is engaged in a vigorous debate on globalisation and recently those on the other side of the debate, the anti-globalisation movement, has resorted to physical actions to back up their rhetoric. They have protested against International Monetary Fund (IMF)/World Bank, World Trade Oganisation (WTO) and G8 policies, on behalf of African countries where the negative impact of globalisation has been felt. However, if people in the Western states and Europe are protesting on behalf of Africa and the $3^{\text {rd }}$ world, then what are the affected countries doing? Are we saying globalisation is unstoppable? 


\section{The Place of Education in the Face of Challenges Posed by Globalisation}

It is an undeniable fact that we are living in a world full of inequalities: inequalities within nations and inequalities, particularly between nations. Inequalities often bring in their wake injustices, alienation, and even destitution.

Yet, ours is a world that has pushed the frontiers of knowledge and information so far that we can claim that we could have within our reach, the very necessary means for our salvation and for the solution of many problems, challenges and scourges that are the bane of our societies today. However, there are certain issues and questions that we can safely take for granted. For example, we have come to accept the idea of globalisation as a fait-accompli, brooding inevitability, haunting us and yet full of promise and maybe, the reality of a shrinking world and the undeniable commonality of our future. Supporting this idea, Borisade (2001) argues that there are of course, diversities in the way we view, appreciate, perceive, and assess these realities.

Similarly, there are also staggering differences, some of them quite outrageous, in the manner the so-called global village situation affects and touches our different societies. The 'haves' shall have more, and the 'have-nots' shall lose even the little they have. If that-logic were to persist, then some, that is, a sizeable portion of the world are condemned to be unequal inheritors of the earth.

In any case, nations all over the world have always agreed that progress in any endeavour to develop human and material resources is not possible if there is no education. The new thinking therefore is that education could be used as a potent tool for achieving equality, peace, and global development.

Therefore, as globalisation spreads its pervasive influence all over the world, there are still vast areas of the world where national cohesion, awareness and solidarity must continue to be the immediate hallmark of national development and aspirations. For it is only nations, deeply steeped in their national cultures and with firmly established educational policies and structures for national well being that can contribute meaningfully to the dialogue between nations. The dialogue must be based on mutual respect, and the search for partnership for the common good.

For Africa to be relevant in the global village Africans should be committed to building a society that is united, conscious of its heritage and proud of its 
culture and institutions. That is why there is a need for an overhaul of Africa's educational system. Education, must have all the necessary ingredients for making every African a worthy citizen, enabled to contribute to and profit from the development of their country and well prepared and equipped for citizenship of the world at large. This can only be possible if there are major innovations in the syllabuses, methodologies, and learning situations, as well as more open and wide-ranging policies for teaching languages, science and the use of new technologies. What these reveal is that education remains a source of hope as a human right, whose achievement will make a contribution to other rights and human development, of which the ability to live together is an unavoidable condition.

\section{Africanising Education}

Having considered the place of education in the face of challenges faced-by globalisation, the question that arises is: How do we now make African education relevant or popular in this era of global village?

It is a fact that human society, socialisation and development show qualitative progress by the means and ways through which a people's heritage is preserved, transmitted, and internalised. This is especially so with regard to learning/training systems. Before the invention of writing, learning was done through a simple system described by Ekwealo (2000) as verbal and other signs, but later became codified in forms of writing. In contemporary times however, the computer has been developed into a valuable training tool. It is these various means of transmitting values and the contents of these social experiences that constitute education, which may be formal or informal or both.

Since every society has its own distinct culture, norms and practices, educational content was normally dependent on and/or aligned to the people's peculiar mental spectables and worldview. However, what constitutes the content of education according to Ekwealo (2000:16) was designed and packaged by the ruling class, the power wielders in the society . Marx and Mosca have described them as the capitalist class, whose consciousness and relations with others tend to be dictated always by exploitation and self-interest.

With the eventual emergence of formal states and nation-states, education became more politically packaged and influenced. Any nation or empire that emerges as victor in war or international diplomacy always wants to impose its educational values/worldview on the weaker nations. Needless to say, this worldview, which is usually not in harmony or attunement with the conscious- 


\section{Zimbabwe Journal of Educational Research}

ness of the conquered or 'protected' territories, constitutes the mental and physical foundation of the education and learning of the conquered.

In Africa, this imposition of values not in conformity with the people's authentic socio-cultural background and ontology came with Arab and European imperialism. The content of learning and experience prepared for Africans within this context were not conducive to genuine growth and progress. The absurdity of the situation was graphically expressed by the late Nigerian Afrobeat musician, Fela Anikulapo-Kuti, when he reminded Africans in one of his songs that Mungo Park did not discover the mouth of the River Niger in Nigeria as taught by the British colonialists, instead, African scouts and guides led and escorted Park to the "discovered" geographical landmark! Unfortunately, African pupils are still taught this glaring untruth to this today.

The effect of all the negative mental programming and indoctrination was to make Africa and Africans a perpetual dependent society, incapable of conceiving a distinctly original worldview, heritage and development plan. Consequently, Africa has become an environment of poverty, disease, death and underdevelopment. All these in the area of globalisation call for a critical reflection on the politics of education in order to protect and project African interests.

The late Professor Claude Ake drew Africans' attention to the dangers inherent in the continent's dependent relationship with Western imperialism, when he noted, "to begin with, the Third world remains very useful as an outlet for surplus capital as well as a source of profit and income from the West to the Third World. Capitalist rationality would normally require control over such sources of surplus. Second, despite the increasing self-sufficiency of the West, made possible by the invention of synthetic substitutes of raw materials, the West depends heavily on the Third World for many vital industrial inputs and minerals. Therefore the battle is on for the control of the Third World, and one of the critical areas in which this battle will be fought is the mind". Ake went on to reveal, "Western social science scholarship on Africa and other Third World regions is an important weapon in this battle. Western social science on the Third World constitutes imperialismbecause Western scholarship is an important tool for controlling Third World perceptions of their world and their problems andleventually their behaviour". Ake's submission constitutes significant revelation for and challenges to African and Third World education.

The African philosophy/policy of education should be anchored on its own pristine, existential background, for it is what forms Africans' principle of un- 
derstanding and their worldview. Consequently, the right of education of Africans must start on a mental level where the people and their leaders begin to liberate themselves from the values and systems with which they have been indoctrinated by their imperial masters and in which they are being dragged in the name of globalisation. In other words, a radical restructuring of African educational base.is called for.

According to Franz Fanon, the task of putting Africa on the respectable map of history in this era of globalisation is in the hands of nationalistic African intellectuals, resèarchers, and education planners.

\section{Conclusion}

It has been argued in this paper that the reality of globalisation, demands a critical examination, and understanding of the place of the African people. We have in the course of this paper also identified as particularly worrisome, the assault of Black African cultures, values and education in the effort to portray them as less functional and perhaps, inferior to that of other races.

We observed for instance that, through the instrumentality of science and technology all in the name of globalisation, cultures, values; and education of other parts of the world are daily promoted and propagated to the disadvantage of Africa. We also observed the very disturbing development by which an average African youth is increasingly succumbing to the notion of an inferior status of his culture. This represents a growing tragedy, which calls for urgent reversal. In this era of the global village, we cannot afford to be complacent while our culture, values, and education are eroded and our intellectual achievements given little or no prominence.

Though globalisation becomes necessary because it is a reality that Africa must come to terms with, history should be recognised with regard to the fact that Africa is the birthplace of man and the cradle of civilisation. Yet for many centuries now, this culture and contributions made to world progress and development have been under-acknowledged and abbreviated, they have continued to be the object of the most brazen and protracted assault.

One of the most compelling challenges before the entire Black and African race therefore is the maintenance of cultural identity and avoidance of the siege mentality or a new celebration of African values in the abstract. Africa must probe how it will function in the new modernity. There must be a negotiation between African cultures and the structures of the modern world, which is 
determined by science and technology, to promote certain kinds of values that are in tune with this new civilization.

Every knowledge must therefore be tapped so that African nations can compete favourably in the global game: African governments and leaders are thus called upon to overhaul their education and promote indigenous culture and values to avoid marginalisation of Africa in the global village.

\section{References}

Achebe, C. (1983). The trouble with Nigeria. Enugu Fourth Dimension Publishers.

Adeşanya, L.A. (2000). Globalization and educational innovation: The challenges ahead. $12^{\text {th }}$ Annual Conference of the Curriculum Orgnaization of Nigeria (CON) held at Abubakar Tafawa Balewa University, Bauchi. September 26-29, 1999 .

Ake, Claude (1992). Rethinking African democracy. Accra: Policy Analysis Institute of Economic Affairs.

Babarinde, Kola (2000). Globalization and its challenges for educational theorising in Africa. $18^{\text {th }}$ Annual Conference of Philosophy of Education Association of Nigeria (PEAN) held at the University of Ibadan, Nigeria, October 16-19, 2000.

Basil, D. (1993). The African man's burden. Ibadan Spectrum Books Limited.

Cornford, F.M. (1979). The republic of Plato. London: Oxford University.

Dembele, D.M. (1999). The political economy of debt adjustment and globalization in Africa. In Fall, Y. (ed). 1999, Gender, globalization and resistance. AAWORD Book Series.

Ekwealo, S. (2000). Sunday Purch, December 3, 2000, p.16.

Kwanashie, M. Op Cit. pp. 340-351.

Majabau, J.A. (1967). Yoruba education: Its principles; practice and relevance to current educational development. Unpublished $\mathrm{PhD}$. Thesis, University of Ibadan, Nigeria.

Marshal(1994). Dictionary of sociology.

Olusanya, P.O. \& Olurode L. (eds.)(1988). Readings in introductory sociology. John-West Publications. 
Globalization and African Challenge. The Comet. Thursday, August 23, 2001, 35.

Globalization: A challenge to developing countries. The Comet; Wednesday, August 29, 2001. Editorial, 17.

Education as a tool for global peace. The Guardian, Thursday, September 20, 2001 pp. 39.

Nigeria and Globalization. This Day. Wednesday, September 12, 2001 (2334), 43.

Rodney, W. (1978). How Europe underdeveloped Africa. London: BogleL'Ouverture Publications. 


\section{(c) (1) (9)}

This work is licensed under a

Creative Commons

Attribution - NonCommercial - NoDerivs 3.0 License.

To view a copy of the license please see:

http://creativecommons.ora/licenses/bv-nc-nd/3.0/ 